\title{
Moisture sorption isotherms of fresh and blanched pumpkin (Cucurbita moschata)
}

\author{
Isotermas de sorção de umidade de abóbora (Cucurbita moschata) fresca e branqueada
}

\author{
Lucídio MOLINA FILHO ${ }^{1}$, Ana Karla Rebes GONÇALVES ${ }^{1}$, \\ Maria Aparecida MAURO $^{1 *}$, Elen Cristina FRASCARELI ${ }^{1}$
}

\begin{abstract}
Moisture desorption isotherms of fresh and heat blanched pumpkins (Cucurbita moschata) were determined at three temperatures (30, 50 and $70^{\circ} \mathrm{C}$ ), using the standard, static-gravimetric method. The GAB, Oswin, BET, Halsey, and Henderson models were tested and, with the exception of the Henderson model, showed satisfactory fits to the experimental data. The GAB model was used to analyze the fitting ability to describe the isotherm type. The shape of the desorption isotherms of fresh and blanched pumpkin at 30 and $50{ }^{\circ} \mathrm{C}$ was intermediate to types II and III, and at $70^{\circ} \mathrm{C}$ it was of type II for the blanched pumpkin and close to type II for the fresh sample. The influence of blanching on the decrease in equilibrium moisture was very small compared to the fresh samples and it was related to the loss of soluble solids during the pre-treatment. The isosteric heat of sorption measures indicated that a larger amount of heat was required to remove the water from the fresh samples than from the blanched ones.

Keywords: blanching; pumpkin; desorption isotherms; isosteric heat; GAB model.
\end{abstract}

\section{Resumo}

Isotermas de sorção de umidade de abóboras frescas e branqueadas termicamente foram determinadas em três temperaturas $\left(30,50\right.$ e $\left.70{ }^{\circ} \mathrm{C}\right)$, utilizando o método estático gravimétrico padrão. Os modelos de GAB, Oswin, BET, Halsey e Henderson foram testados e, com exceção do modelo de Henderson, mostraram ajuste satisfatório aos dados experimentais. O modelo de GAB foi usado para analisar a habilidade do ajuste na descrição do tipo de isoterma. A forma das isotermas de dessorção de abóbora fresca e branqueada determinadas a 30 e $50{ }^{\circ} \mathrm{C}$ foi intermediária aos tipos II e III e a $70^{\circ} \mathrm{C}$ foi do tipo II para abóbora branqueada e próxima ao tipo II para abóbora fresca. A influência do branqueamento sobre a redução da umidade de equilíbrio das amostras foi muito pequena em comparação com amostras frescas e foi relacionada à perda de sólidos solúveis durante o pré-tratamento. Os valores de calor isostérico de sorção para tecido de abóbora indicaram que maior calor foi requerido para remover água das amostras frescas do que das amostras branqueadas.

Palavras-chave: branqueamento; abóbora; isotermas de dessorção; calor isostérico; modelo de GAB.

\section{Introduction}

Pumpkins, which are widely cultivated in Brazil, are a good source of carotenoids, mainly a-carotene and $\beta$-carotene, components that present pro-vitamin A activity (RODRIGUEZ-AMAYA; KIMURA; AMAYA-FARFAN, 2008). The consumption of carotenoid-rich foods has been associated with the prevention of cancer, macular degeneration and other degenerative diseases, mostly related to their antioxidant and free-radical scavenging properties (KRINSKY, 1993).

Drying is one of the most widely used primary methods of food preservation, aiming to reduce the water content to a level at which microbial and deterioration reactions are greatly minimized (DOYMAZ, 2007, AKPINAR; BICER, 2005). Drying also contributes to a reduction in production losses and to an extension in storage life, thus making seasonal foods available throughout the year. However, physical, chemical and biochemical transformations occurring during air-drying represent one of the main problems that may lead to product quality depreciation (MUJUMDAR, 1997), since the maximum temperatures used in food drying are generally not high enough to inactivate the enzymes. The application of heat blanching to fruits and vegetables before air-drying is, therefore, aimed at stopping enzymatic activity and avoiding undesirable changes to the sensory and nutritional properties during drying and storage, enhancing product quality (CHANTARO; DEVAHASTIN; CHIEWCHAN, 2008; WOLFE; LUI, 2003).

Drying processes and dryer design require knowledge of the relationship between water content and vapor pressure equilibrium, since the vapor pressure gradients are the essential driving forces during these processes (VAN DEN BERG; BRUIN, 1981). Due to its importance in dehydration processes, rehydration conditions, as well as in packaging and in quality changes during storage, the sorption of water vapor by foods has received much attention (VEGA-GÁLVEZ et al., 2009; MOREIRA; CHENLO; TORRES, 2009; MORAES; ROSA; PINTO, 2008; PARK; YADO; BROD, 2001). The sorption isotherm consists of a graphic representation of the relationship

Received 28/11/2009

Accepted 5/6/2010 (004521)

${ }^{1}$ Department of Food Engineering and Technology, Institute of Biosciences, Language, and Physical Sciences - IBILCE, Sao Paulo State University - UNESP,

Rua Cristóvão Colombo, 2265, CEP 15054-000, São José do Rio Preto, SP, Brazil, e-mail: cidam@ibilce.unesp.br

*Corresponding author 
between the water content and the equilibrium relative humidity at constant temperature. The knowledge of the moisture sorption isotherm data as a function of two or more temperatures is important for the thermodynamic analysis and modeling of drying kinetics, and it is also useful to evaluate food stability during storage (VEGA-GÁLVEZ et al., 2007). The knowledge of the thermodynamic properties can also provide information about the food microstructure as well as allowing for the theoretical interpretation of physical phenomena occurring at the water-food interface (RIZVI, 1995).

Water affects the physical nature and properties of food in a complex way due to interactions with their solutes, colloids and dispersed particles (PARK; YADO; BROD, 2001). The water activity of food reflects the availability of water for deteriorative reactions and microbiological growth and it is one of the major control variables in food preservation technology (VAN DEN BERG; BRUIN, 1981).

Many theoretical, partially theoretical and empirical models can be found in the literature for the mathematical description of food system moisture sorption (VAN DEN BERG; BRUIN, 1981). Boquet, Chirife and Iglesias (1978) evaluated the usefulness of eight two-parameter isotherms in describing the moisture sorption isotherms of 39 different nature foods and found that the most versatile models were those of Halsey and Oswin. In addition, the Henderson model has found many practical applications, and it is one of the only equations including a direct temperature term (VAN DEN BERG; BRUIN, 1981).

The BET model, based on the multi-layer adsorption of water, is considered the best model for interpreting sorption isotherms (MATHLOUTHI; ROGÉ, 2003). Of all the multi-layer models available for sorption, this model acts as a useful compromise between theory and practice, since the equation parameters have physical significance and the model has the ability to fit sigmoidal sorption isotherms up to an $\mathrm{a}_{\mathrm{w}}$ of about 0.4 (VAN DEN BERG; BRUIN, 1981). The GAB model was considered an important improvement on the BET equation, and its application has shown a good fit up to an $\mathrm{a}_{\mathrm{w}}$ of 0.9 (VAN DEN BERG; BRUIN, 1981, LEWICKI, 1997).

The calculation of the energy consumption during drying demands knowledge of the enthalpy of water sorption throughout the entire range of moisture contents (TSAMI, 1990). The enthalpy of sorption yields a figure for the theoretical minimum amount of heat required to remove a given amount of water (RIZVI; BENADO, 1984).

The purpose of this work was to evaluate the influences of temperature and heat blanching on the behavior desorption isotherms and on the isosteric heat of sorption of pumpkins.

\section{Materials and methods}

\subsection{Materials}

Mature pumpkins (Cucurbita moschata) of the 'Rajada Seca Melhorada' cultivar, with a total weight of approximately $40 \mathrm{~kg}$, were obtained from the local market
(CEAGESP - São José do Rio Preto, State of São Paulo, Brazil) and stored at room temperature $\left(25^{\circ} \mathrm{C}\right)$. Saturated aqueous salt solutions were prepared using $\mathrm{NaOH}, \mathrm{LiCl}, \mathrm{CH}_{3} \mathrm{COOK}, \mathrm{MgCl}_{2}$, $\mathrm{K}_{2} \mathrm{CO}_{3}, \mathrm{NaBr}, \mathrm{NaNO}_{2}, \mathrm{NaCl}, \mathrm{KCl}$ and $\mathrm{BaCl}_{2}$ (all analytical grade) and commercial formaldehyde (40\%) was used for cleaning the material.

\subsection{Samples}

The pumpkins were cut into portions transversally to their axes, and the extremities were discarded. Each portion was cut into longitudinal pieces, peeled, seeded and sliced $\left(4 \times 10^{-3} \mathrm{~m}\right.$ thickness). To standardize the samples, circles were cut from the slices using a cork borer with a $2.8 \times 10^{-2} \mathrm{~m}$ diameter, and then a $2.2 \times 10^{-2} \mathrm{~m}$ plug was removed from the center of each circle and discarded. The resulting rings were put in a plastic bag, mixed and divided in two portions, one for fresh and one for blanched sampling.

\subsection{Blanching}

The pumpkin rings $(0.4 \mathrm{~kg})$ were placed in a wire basket, immersed in boiling water $\left(2.0 \times 10^{-2} \mathrm{~m}^{3}, 98,3^{\circ} \mathrm{C}\right)$ for 60 seconds, cooled with tap water for a further minute, drained and dried with absorbent paper.

\subsection{Sorption isotherms}

The gravimetric static method (RIZVI, 1995) was employed to determine the equilibrium moisture of fresh and blanched pumpkin at 30,50 and $70{ }^{\circ} \mathrm{C}$. Saturated salt solutions were prepared in glass flasks previously cleaned with formaldehyde (40\%) to avoid microbial growth. The relative humidity ranged from 5 to $90 \%$, obtained using ten salts: $\mathrm{NaOH}, \mathrm{LiCl}$, $\mathrm{CH}_{3} \mathrm{COOK}, \mathrm{MgCl}_{2}, \mathrm{~K}_{2} \mathrm{CO}_{3}, \mathrm{NaBr}, \mathrm{NaNO}_{2}, \mathrm{NaCl}, \mathrm{KCl}$ and $\mathrm{BaCl}_{2}$. Five gram samples (in triplicate) of fresh and blanched pumpkin were weighed in plastic baskets and placed in the glass flasks on top of acrylic tripods arranged in the flasks to maintain the samples above the solutions. Fresh and blanched samples were characterized with respect to total solids and sugars in independent assays. Each flask, containing three fresh and three blanched samples, was hermetically closed and placed in a temperature-controlled incubator. A BOD incubator was used at 30 and $50^{\circ} \mathrm{C}$ (sensor PT100, $\pm 0,1 \mathrm{C}$ precision and $\pm 1^{\circ} \mathrm{C}$ homogeneity). An oven with air circulation was used at $70^{\circ} \mathrm{C}$ (type J sensor, $\pm 2{ }^{\circ} \mathrm{C}$ precision and $\pm 4{ }^{\circ} \mathrm{C}$ homogeneity). The samples were weighed periodically until constant weight. The total solids contents were then determined, as well as the average equilibrium moisture contents related to the corresponding water activity.

\subsection{Analytical methods}

The solids contents of the fresh and blanched samples were determined gravimetrically by drying to constant weight in a vacuum oven at $60^{\circ} \mathrm{C}$ and $10 \mathrm{kPa}$. The reducing and total sugar contents were determined by oxy-reduction titration (ASSOCIATION..., 1970). 
Table 1. Water sorption isotherm models.

\begin{tabular}{ccc}
\hline Model & Equation \\
\hline BET & $X=\frac{X_{m} \cdot C \cdot a_{w}}{\left(1-a_{w}\right)\left(1+(C-1) a_{w}\right)}$ \\
\hline GAB & $X=\left[\frac{X_{m} \cdot C \cdot K \cdot a_{w}}{\ln \left(a_{w}\right)}\right]^{\frac{1}{b}} \quad(1)$ \\
\hline Halsey & $X=\left[\frac{\ln \left(1-a_{w}\right)}{a}\right]^{\frac{1}{b}} \quad a=k T, \quad T$ em ${ }^{\circ} R a$ \\
\hline Henderson & $X=a\left[\frac{a_{w}}{\left(1-a_{w}\right)}\right]^{b}$ \\
\hline Oswin & $(3)$ \\
\hline
\end{tabular}

Where $C, K, a$ and $b$ are constants; $a_{w}$ is the water activity; $X$ represents the moisture content on a dry weight basis (kg water/kg dry matter) and $X_{m}$ is the monolayer of water (kg water/kg dry matter).

\subsection{Mathematical modeling}

\section{Sorption isotherms}

BET, GAB, Halsey, Henderson and Oswin models (Table 1) were fitted to the food system moisture sorption.

\section{Net isosteric heat of sorption}

The net isosteric heat of sorption of water $\left(q_{s t}\right)$ can be determined from Equation 6, which is derived from the Clausius - Clapeyron equation, applied to food and pure water (RIZVI, 1995).

$\left.\frac{\partial \ln \left(a_{w}\right)}{\partial(1 / T)}\right|_{X}=-\frac{Q_{s t}-\lambda}{R}=-\frac{q_{s t}}{R}$

where $Q_{s t}$ is the integral isosteric heat of sorption $\left(\mathrm{kJ} \cdot \mathrm{mol}^{-1}\right), \lambda$ the molar enthalpy of vaporization of pure water $\left(\mathrm{kJ} \cdot \mathrm{mol}^{-1}\right), R$ the gas constant $\left(\mathrm{kJ} \cdot \mathrm{mol}^{-1} \cdot \mathrm{K}^{-1}\right)$ and $T$ the temperature $(\mathrm{K})$. The net isosteric enthalpy is obtained by subtracting the value obtained for the corresponding equation for pure water.

The net isosteric heat of sorption can be calculated from Equation 6 by plotting the sorption isostere as $\ln \left(a_{w}\right)$ against $(1 / \mathrm{T})$ for a specific moisture content of the material and determining the slope, which equals $\left(Q_{s t} / R\right)$ (TSAMI et al., $1990)$. This procedure is repeated for different moisture contents in order to determine the dependence of $\left(q_{s}\right)$ on the moisture content $(X)$. The method presents an overall error due to plotting graphical differentiation (KAYMAK-ETERKIN; GEDIK, 2004).

An empirical exponential relationship between the net isosteric heat of sorption $\left(q_{s t}\right)$ and the moisture content $\left(X_{e q}\right.$, dry basis) was proposed by Tsami et al. (1990) in the following form (Equation 7):

$q_{s t}=q_{0} \exp \left(-X / X_{0}\right)$ where $q_{0}=q_{\text {st }}$ at $X=0$ and, at $X=X_{0}, q_{s t}=0.368 q_{0}$. The constant $X_{0}$ is the characteristic moisture content (kg water $\mathrm{kg}^{-1}$ dry matter) of a food material in which the net isosteric heat of sorption has been reduced by $63 \%$. Due to exponential decay, the net isosteric heat of sorption becomes very small at high moisture contents.

\subsection{Statistic methods}

The efficiency of fit was evaluated based on the adjusted coefficient of determination $\left(R^{2}\right)$ and on the mean relative modulus, P, defined by Equation 8 (LOMAURO; BAKSHI; LABUZA, 1985),

$P(\%)=\frac{100}{n} \sum_{1}^{n} \frac{\left|y^{\exp }-y^{\text {calc }}\right|}{y^{\exp }}$

where $y^{\exp }$ represents the experimental value, $y^{\text {calc }}$ the calculated value and $n$ is the number of the observations.

The graphic software ORIGIN v. 5.0 (MICROCAL SOFTWARE, 1997), which adjusts non-linear functions, was used to determine the adjustment constants of the isotherms (Equation 1 to 5) and Equation 7.

\section{Results and discussion}

\subsection{Sorption isotherms}

The equilibrium moisture contents experimentally determined at temperatures 30,50 and $70{ }^{\circ} \mathrm{C}$ were compared to the values calculated according to the $\mathrm{GAB}$ equation (Equation 2) for fresh (Figure 1) and blanched (Figure 2) pumpkin. The desorption curves showed that, at constant water activities, the values for the equilibrium moisture content decreased with as the temperature increased, following the same tendency of most agricultural products (RESENDE et al., 2006). The influence of blanching on the pumpkin isotherms 
was small, showing a behavior quite similar to that of fresh pumpkin isotherms. Nevertheless, the blanched samples showed slightly lower values for the moisture equilibrium than the fresh ones at 30 and $50^{\circ} \mathrm{C}$ (Figures 3 and 4, respectively). Moreover, as the temperature increased, the difference between fresh and blanched curves diminished at low and intermediate moisture levels and even showed a small inversion at $70{ }^{\circ} \mathrm{C}$ (Figure 5).

Independent tests were carried out to characterize the fresh and blanched samples (Table 2). The total sugar loss during

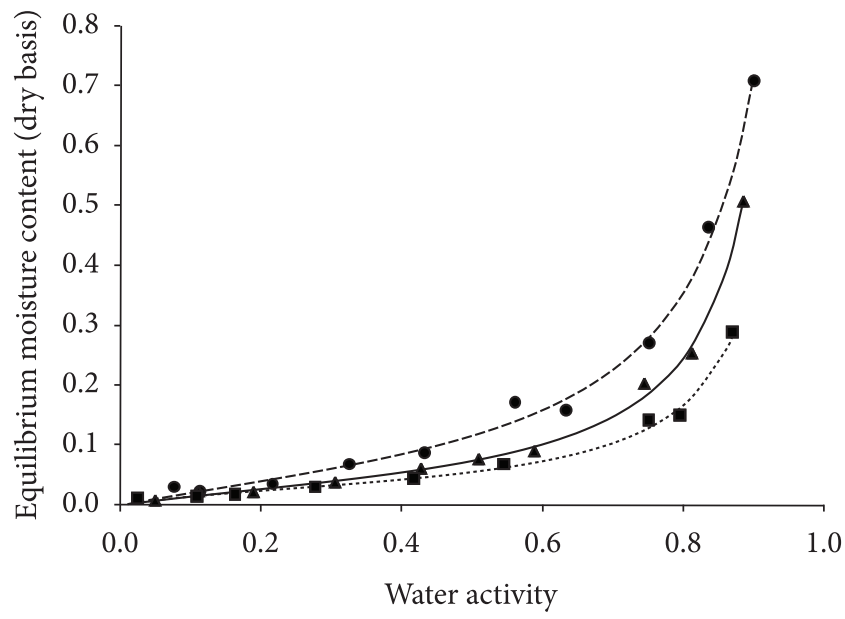

- Fresh $\exp 30^{\circ} \mathrm{C} \quad-$ Fresh calc $30^{\circ} \mathrm{C}$ • Fresh $\exp 50^{\circ} \mathrm{C}$

- Fresh calc $50^{\circ} \mathrm{C}$ - Fresh $\exp 70^{\circ} \mathrm{C} \quad \cdots$ Fresh calc $70^{\circ} \mathrm{C}$

Figure 1. Comparison between experimental and calculated (GAB model) equilibrium moisture contents (dry weight basis, dwb) for fresh pumpkin at 30,50 and $70{ }^{\circ} \mathrm{C}$.

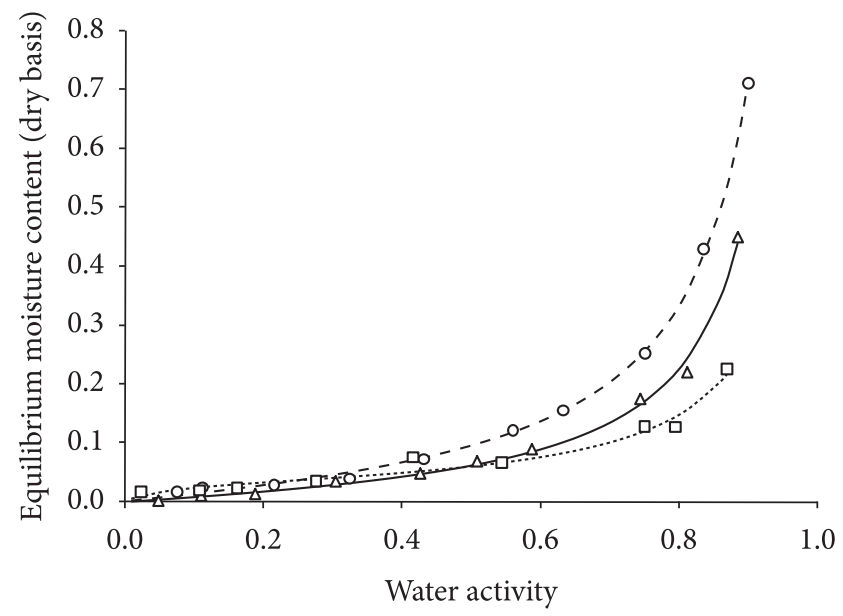

○ Blanched $\exp 30^{\circ} \mathrm{C}-$ Blanched calc $30^{\circ} \mathrm{C}$
$\Delta$ Blanched $\exp 50^{\circ} \mathrm{C}-$ Blanched calc $50^{\circ} \mathrm{C}$
$\square$ Blanched $\exp 70^{\circ} \mathrm{C}-$ - Blanched calc $70^{\circ} \mathrm{C}$

Figure 2. Comparison between experimental and calculated (GAB model) equilibrium moisture contents (dry weight basis, dwb) for blanched pumpkin at 30,50 and $70{ }^{\circ} \mathrm{C}$. blanching was approximately $15 \%$, which can explain the lower equilibrium moisture content of the blanched samples when compared to the fresh ones, since sugars retain a larger amount of water (CHIRIFE; FERRO FONTAN; BENMERGUI, 1980) than cellulosic compounds (PAPADAKIS et al., 1993) and proteins (BULL, 1944), which, together with the sugars, are the major pumpkin components (UNIVERSIDADE..., 2006).

Sorption models (Table 1 ) were tested with experimentally defined equilibrium moisture data (Table 3 ) to describe fresh

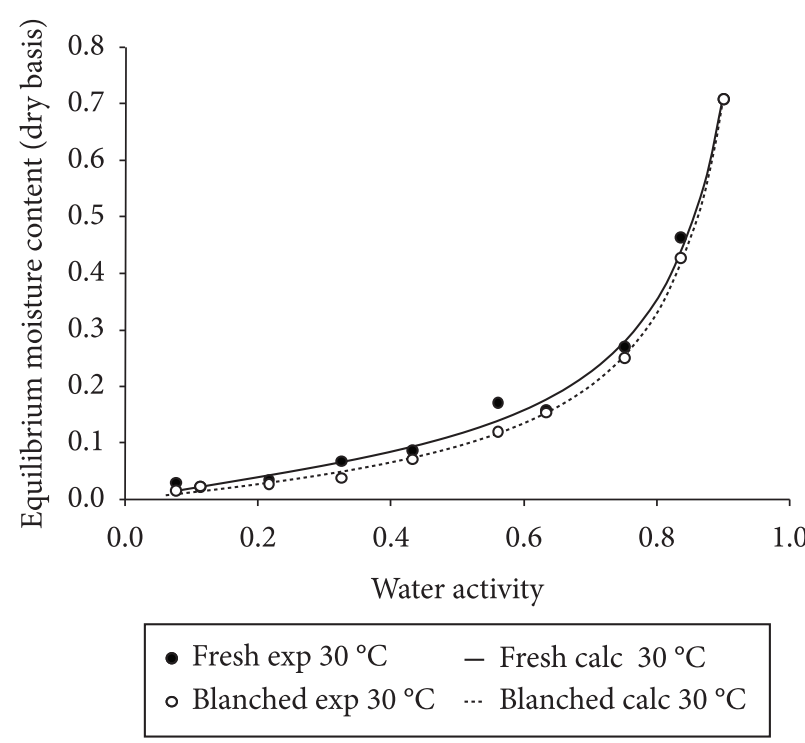

Figure 3. Comparison between experimental and calculated (GAB model) equilibrium moisture contents (dry weight basis, dwb) for fresh and blanched pumpkin at $30^{\circ} \mathrm{C}$.

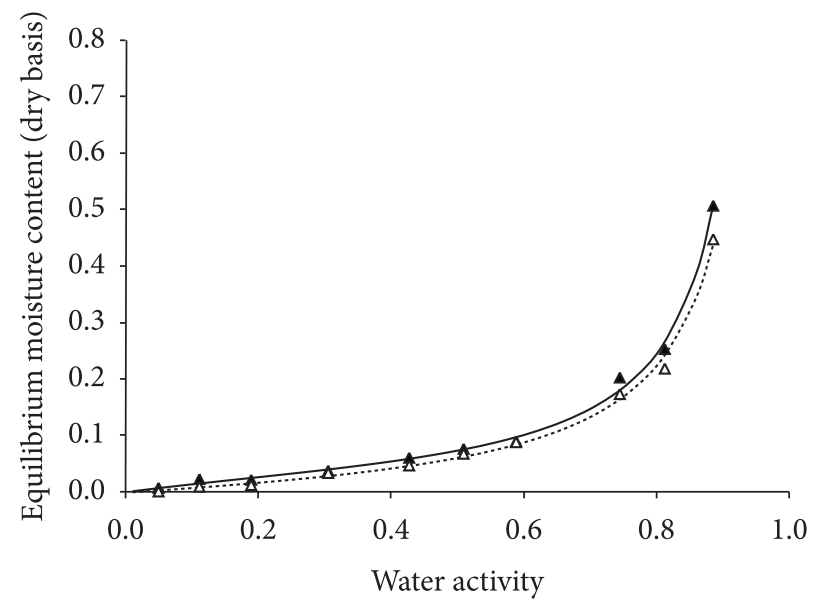

\ Fresh exp $50^{\circ} \mathrm{C} \quad-$ Fresh calc $50{ }^{\circ} \mathrm{C}$

$\Delta$ Blanched exp $50^{\circ} \mathrm{C} \quad \cdots$ Blanched calc $50^{\circ} \mathrm{C}$

Figure 4. Comparison between experimental and calculated (GAB model) equilibrium moisture contents (dry weight basis, $\mathrm{dwb}$ ) for fresh and blanched pumpkin at $50{ }^{\circ} \mathrm{C}$. 
Table 2. Water content and total sugar content, on both wet and dry weight bases, of fresh and blanched pumpkin.

\begin{tabular}{|c|c|c|c|c|c|}
\hline & $\begin{array}{c}\text { Water content } \\
\mathrm{kg} \cdot \mathrm{kg}^{-1} \text { wet matter }\end{array}$ & $\begin{array}{c}\text { Reducing } \\
\text { sugar }\end{array}$ & $\begin{array}{c}\text { Non-reducing } \\
\text { sugar }\end{array}$ & $\begin{array}{l}\text { Total sugar content } \\
\text { kg.kg-1 wet matter }\end{array}$ & $\begin{array}{l}\text { Total sugar content } \\
\text { kg.kg-1 dry matter }\end{array}$ \\
\hline Fresh & 0.9347 & 0.0163 & 0.0170 & 0.0333 & 0.5087 \\
\hline Blanched & 0.9565 & 0.0089 & 0.0099 & 0.0189 & 0.4325 \\
\hline
\end{tabular}

Table 3. Equilibrium moisture content (dry weight basis) of fresh and blanched pumpkin at 30,50 and $70{ }^{\circ} \mathrm{C}$, and corresponding water activity $\left(a_{w}\right)$

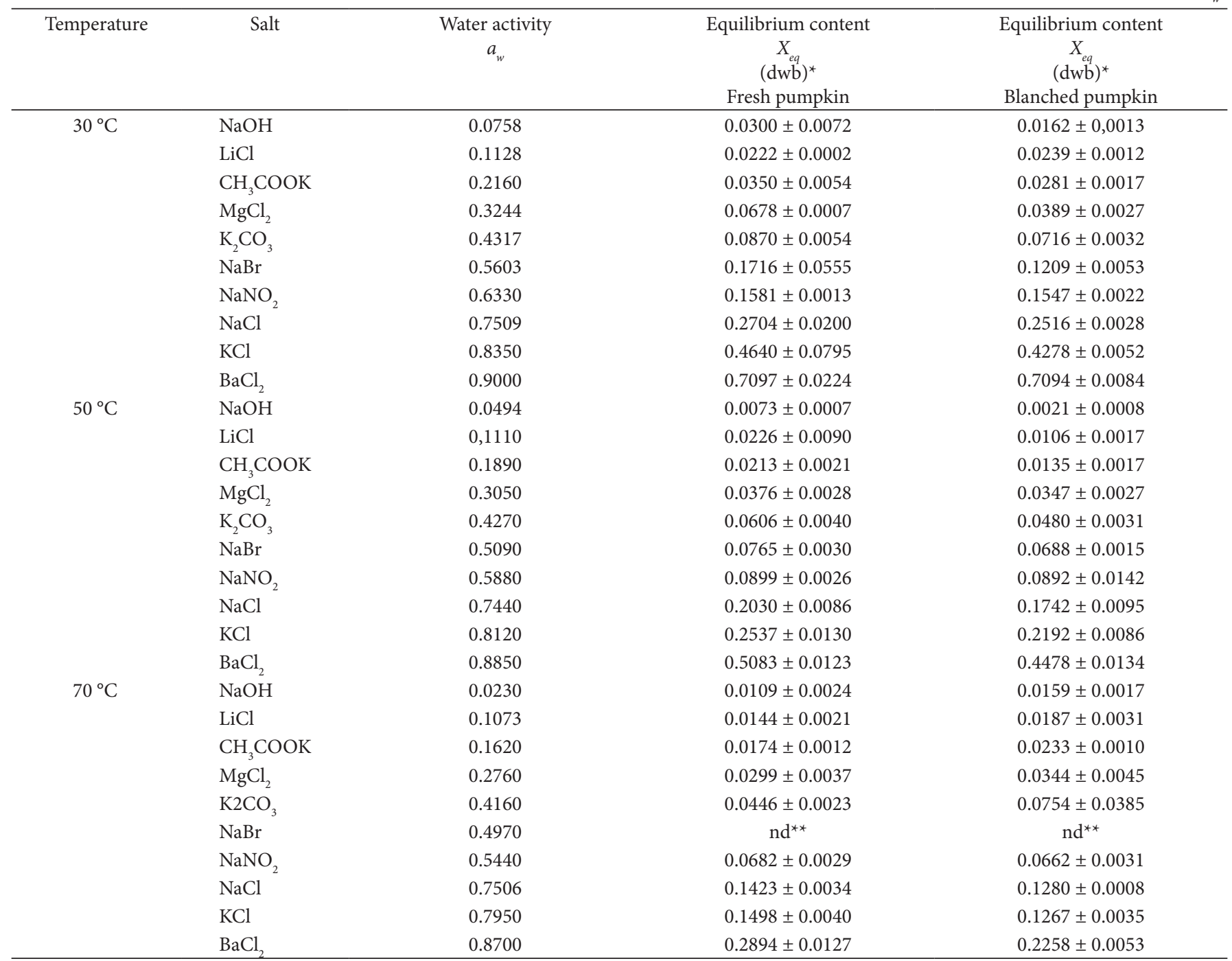

${ }^{\star}$ dwb: dry weight basis; ${ }^{* *}$ non-determined.

and blanched pumpkin sorption isotherm curves. With the exception of Halsey's equation when fitted to $50{ }^{\circ} \mathrm{C}$ data of blanched tissue and Henderson's equation, in general, all the models showed satisfactory adjustments to the experimental data (Table 4). For fresh tissue data, the best fitting was obtained through BET and GAB equations, since the values for $R 2$ were always higher than 0.98 and $P$ values were lower than $13.3 \%$. The blanched tissue showed a satisfactory fit to GAB, BET, Halsey and Oswin models only at $30^{\circ} \mathrm{C}\left(R^{2}>0.99\right.$ and $\left.\mathrm{P}<12.6 \%\right)$. For $50{ }^{\circ} \mathrm{C}$ isotherm, BET, GAB and Oswin models were acceptable
$\left(R^{2}>0.99\right.$ and $\mathrm{P}<17.5 \%$ ), while for $70{ }^{\circ} \mathrm{C}$ isotherm, BET, $\mathrm{GAB}$, Halsey and Oswin models showed $R 2>0.95$ and $\mathrm{P}<17.9 \%$.

$P$ modulus value below $10 \%$ is an indicative of a good fit for practical purposes (LOMAURO; BAKSHI; LABUZA, 1985). However, the $P$ presented values are justified by the low equilibrium moisture contents obtained in relative humidity around $5 \%$, since the $P$ calculation is based on the relative residual (Equation 8), which amplifies the deviations when the moisture content is quite low. 
Five types of isotherms are described by Brunauer (BRUNAUER et al., 1940; INTERNATIONAL..., 1985) The GAB model describes sigmoidal type isotherms (type II) well and fulfils the requirements of the BET model when the parameters are kept within the following regions: $0.24<K \leq 1$ and $5.67 \leq C \leq \infty$. Outside these regions the isotherm is either no longer sigmoidal or the monolayer capacity is estimated with an error greater than $\pm 15.5 \%$ (LEWICKI, 1997).

Table 4 shows that only the fresh and blanched pumpkin curves prepared at $70{ }^{\circ} \mathrm{C}$ complied with the requirement for parameter $C$, and that only the blanched one complied with parameter $K$. The other isotherms, adjusted using the GAB model, presented parameter $C$ outside the band, showing mixed behavior between types II and III (slightly sigmoidal). Mayor et al. (2005) also found forms of fresh pumpkin parenchyma isotherms (cv Cucurbita Pepo L.) between types II and III at 5, 25 and $45^{\circ} \mathrm{C}$.

Figures 6 and 7 show the curves for the neperian logarithm of water activity $\left(\ln \left(a_{w}\right)\right)$ as a function of the inverse values of the absolute temperature $(1 / T)$ for specific values of equilibrium moisture $(\mathrm{dwb})$ for fresh and blanched pumpkin, respectively.

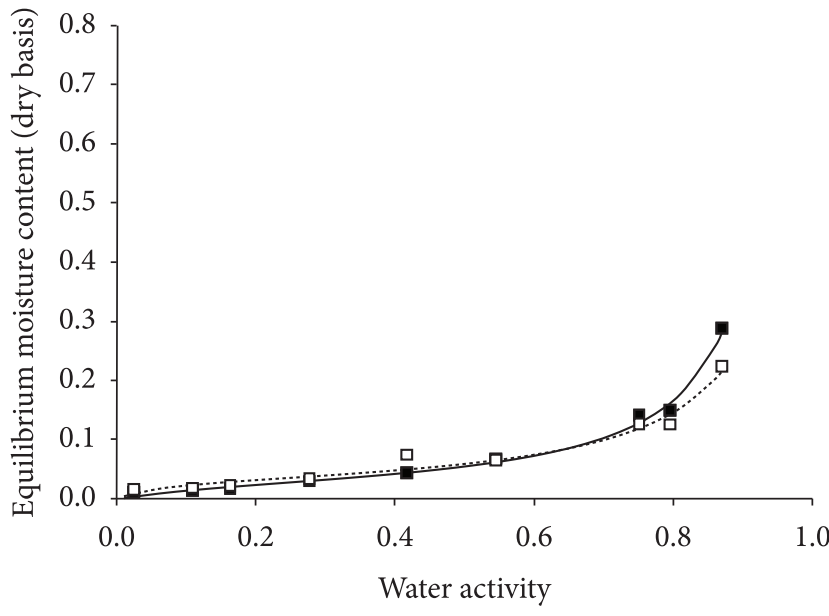

- Fresh $\exp 70^{\circ} \mathrm{C} \quad-$ Fresh calc $70^{\circ} \mathrm{C}$

- Blanched $\exp 70^{\circ} \mathrm{C} \quad \ldots$ Blanched calc $70^{\circ} \mathrm{C}$

Figure 5. Comparison between experimental and calculated (GAB model) equilibrium moisture contents (dry weight basis, dwb) for fresh and blanched pumpkin at $70^{\circ} \mathrm{C}$.

Table 4. BET, GAB, Halsey, Henderson and Oswin model fitting constants for fresh and blanched pumpkins, determined at 30,50 and $70{ }^{\circ} \mathrm{C}$; corresponding $R 2$ and RMSR.

\begin{tabular}{|c|c|c|c|c|c|c|c|c|c|}
\hline \multirow[t]{2}{*}{ Sample } & \multirow[t]{2}{*}{ Model } & \multirow{2}{*}{$\begin{array}{c}\mathrm{T} \\
\left({ }^{\circ} \mathrm{C}\right)\end{array}$} & \multirow[t]{2}{*}{$R^{2}$} & \multirow{2}{*}{$\begin{array}{c}P \\
(\%)\end{array}$} & \multicolumn{5}{|c|}{ Parameters } \\
\hline & & & & & $a$ & $b$ & C & $K$ & $X_{m}$ \\
\hline \multirow[t]{15}{*}{ Fresh } & BET & 30 & 0.9849 & 12.98 & - & - & 3.0505 & - & 0.0759 \\
\hline & & 50 & 0.9877 & 11.40 & - & - & 1.9177 & - & 0.0584 \\
\hline & & 70 & 0.9816 & 13.32 & - & - & 4.2217 & - & 0.0366 \\
\hline & GAB & 30 & 0.9853 & 12.68 & - & - & 2.6575 & 0.9916 & 0.0809 \\
\hline & & 50 & 0.9927 & 8.52 & - & - & 3.2653 & 1.0303 & 0.0460 \\
\hline & & 70 & 0.9846 & 13.30 & - & - & 6.3183 & 1.0267 & 0.0312 \\
\hline & Halsey & 30 & 0.9815 & 13.75 & 0.0796 & 0.9646 & - & - & - \\
\hline & & 50 & 0.9957 & 15.88 & 0.0668 & 0.8796 & - & - & - \\
\hline & & 70 & 0.9908 & 9.01 & 0.0405 & 0.9740 & - & - & - \\
\hline & Henderson & 30 & 0.9570 & 24.10 & 3.1919 & 0.7245 & - & - & - \\
\hline & & 50 & 0.9503 & 29.20 & 3.7861 & 0.6635 & - & - & - \\
\hline & & 70 & 0.9426 & 25.56 & 6.9871 & 0.8525 & - & - & - \\
\hline & Oswin & 30 & 0.9852 & 19.50 & 0.1169 & 0.8189 & - & - & - \\
\hline & & 50 & 0.9854 & 12.74 & 0.0756 & 0.9001 & - & - & - \\
\hline & & 70 & 0.9769 & 13.27 & 0.0611 & 0.7654 & - & - & - \\
\hline \multirow[t]{15}{*}{ Blanched } & BET & 30 & 0.9926 & 12.59 & - & - & 1.6106 & - & 0.0766 \\
\hline & & 50 & 0.9922 & 16.35 & - & - & 1.3596 & - & 0.0541 \\
\hline & & 70 & 0.9510 & 17.46 & - & - & 22.4103 & - & 0.0296 \\
\hline & GAB & 30 & 0.9926 & 12.57 & - & - & 1.5902 & 0.9993 & 0.0771 \\
\hline & & 50 & 0.9926 & 17.45 & - & - & 1.5621 & 1.0114 & 0.0495 \\
\hline & & 70 & 0.9598 & 17.89 & - & - & 15.5818 & 0.9818 & 0.0322 \\
\hline & Halsey & 30 & 0.9906 & 11.55 & 0.0813 & 0.8775 & - & - & - \\
\hline & & 50 & 0.9657 & 41.44 & 0.0672 & 0.7822 & - & - & - \\
\hline & & 70 & 0.9615 & 12.02 & 0.0213 & 1.2316 & - & - & - \\
\hline & Henderson & 30 & 0.9703 & 24.16 & 3.0064 & 0.6233 & - & - & - \\
\hline & & 50 & 0.9738 & 19.80 & 4.0644 & 0.6540 & - & - & - \\
\hline & & 70 & 0.9240 & 20.39 & 15.7155 & 1.1978 & - & - & - \\
\hline & Oswin & 30 & 0.9927 & 11.96 & 0.0952 & 0.9142 & - & - & - \\
\hline & & 50 & 0.9915 & 16.58 & 0.0618 & 0.9491 & - & - & - \\
\hline & & 70 & 0.9534 & 16.32 & 0.0671 & 0.5789 & - & - & - \\
\hline
\end{tabular}


Figure 8 shows the net isosteric heat of sorption values $\left(q_{s t}\right)$ for fresh and blanched pumpkins according to the equilibrium moisture values (dwb) calculated for different equilibrium moisture contents at 30,50 and $70{ }^{\circ} \mathrm{C}$, using Equation 6. The

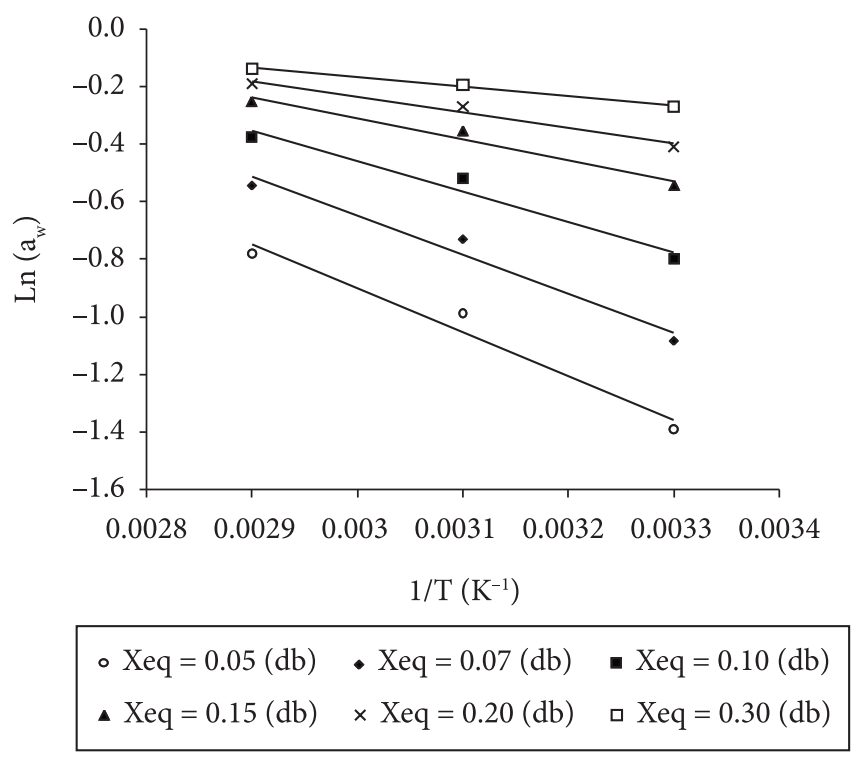

Figure 6. Neperian logarithm of the water activity $\left(\ln \left(a_{w}\right)\right)$ as a function of the inverse values of absolute temperature $(1 / T)$ for the fresh samples.

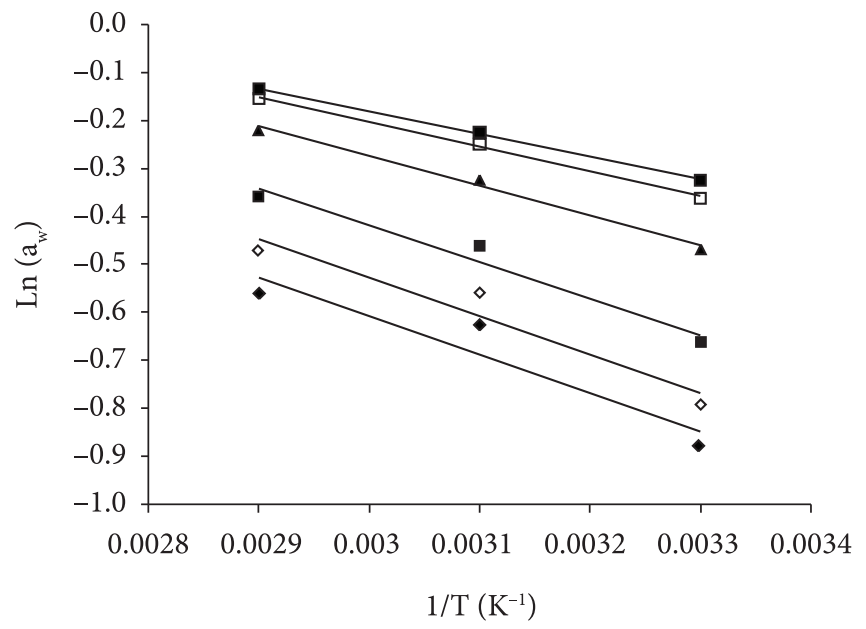

$$
\begin{array}{lll}
\text { - Xeq }=0.07(\mathrm{db}) & \diamond \mathrm{Xeq}=0.08(\mathrm{db}) & \text { - Xeq }=0.10(\mathrm{db}) \\
\text { • Xeq }=0.15(\mathrm{db}) & \text { 口 Xeq }=0.20(\mathrm{db}) & \text { - Xeq }=0.23(\mathrm{db})
\end{array}
$$

Figure 7. Neperian logarithm of the water activity $\left(\ln \left(a_{w}\right)\right)$ as a function of the inverse values of absolute temperature $(1 / T)$ for the blanched samples. net isosteric heat of sorption is represented by the slopes of the lines obtained (Figures 6 and 7), and decreases as the product moisture content increases. Such a behavior can be explained by considering that the sorption of the first layers of water occurs at the most active sites available, originating high energy of interaction (MAZZA; LE MAGUER, 1980). Table 5 shows the values obtained for the constants $q_{0}$ and $X_{0}$, as well as the determination coefficient $\left(R^{2}\right)$ established by fitting Equation 7 to the values of $q_{s t}$ and $X_{e q}$ shown in Figure 8 .

The net isosteric heat of sorption was inversely proportional to the moisture content (Table 5), what was expected due to the higher degree of binding energy of the water to the surface food material for the lower moisture contents (GABAS; MENEGALLI; TELIS-ROMERO, 2000). It can be seen that the heat of sorption of the fresh samples was higher than that of the blanched samples when the moisture content was low. This means that a larger amount of heat is required to remove the water from the fresh sample as compared to the blanched sample. These results were related to the higher sugar contents and the presence of more polar sites on the surface of the fresh tissue.

However, the heat sorption difference decreases as the moisture content increases until this difference is minimal, nearly 0.25 (dwb) (Figure 8). As the moisture increases, the presence of water in the free form increases, which diminishes the binding energy degree and its influence on the net isosteric heat of sorption.

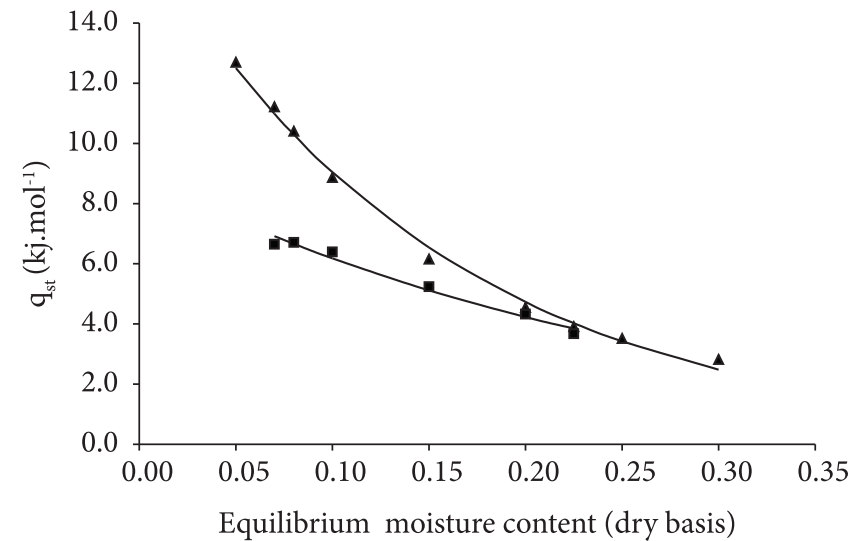

^ Fresh - Blanched

Figure 8. Comparison between the net isosteric heat of sorption values determined by the slopes of the lines obtained (Figures 6 and 7) and calculated (continuous line: Equation 7), as a function of equilibrium moisture content for fresh and blanched pumpkin.

Table 5. The constants $q_{0}$ and $X_{0}$ and the determination coefficient $\left(R^{2}\right)$ established by fitting Equation 7 to the values of $q_{s t}$ and $X_{e q}$ shown in Figure 8 .

\begin{tabular}{lccc}
\hline & $q_{0}\left(\mathrm{~kJ} \cdot \mathrm{mol}^{-1}\right)$ & $X_{0}($ dry basis $)$ & $R^{2}$ \\
\hline Fresh & 17.29 & 0.1544 & 0.9975 \\
Blanched & 9.02 & 0.2645 & 0.9899 \\
\hline
\end{tabular}




\section{Conclusions}

The blanching process had a slight influence on the equilibrium moisture content of the samples, which decreased compared to the fresh samples, this being associated with the loss of soluble solids during the pre-treatment. GAB, Oswin, BET and Halsey models, in general, showed satisfactory fits to the experimental data. The GAB model was used, since its fitted parameters allowed for the analysis of curve types. The isotherms of the fresh and blanched samples determined at 30 and $50{ }^{\circ} \mathrm{C}$ showed behaviors between types II and III. At $70{ }^{\circ} \mathrm{C}$, only the isotherm of the blanched sample clearly showed type II behavior. The behavior of the fresh sample was very similar to that of type II, but one of the parameters did not meet the requirements. The isosteric heats of sorption were quite similar to each other in the moisture levels around 0.25 (dwb). For lower moisture levels, the isosteric heat values indicated that the interactions between solids and water in the fresh samples were stronger than in the blanched ones.

\section{Acknowledgements}

The authors are grateful to FAPESP ('Fundação de Amparo à Pesquisa do Estado de São Paulo') for the financial support (Proc 07/07586-0) and for the studentships (Proc 07/00809-3; Proc. 04/15550-7).

\section{References}

AKPINAR, E. K.; BICER, Y. Modelling of the drying of eggplants in thin-layers International Journal of Food Science and Technology, v. 40 , n. 3, p. 273-281, 2005. http://dx.doi.org/10.1111/j.13652621.2004.00886.x

ASSOCIATION OF OFFICIAL ANALYTICAL CHEMISTS - AOAC. Official Methods of Analysis. 11th ed. Arlington: AOAC, 1970.

BOQUET, R.; CHIRIFE, J.; IGLESIAS, H. A. Equations for fitting water sorption of foods: Evaluation of various two-parameter models. Journal of Food Technology, v. 13, n. 4, p. 319-327, 1978. http:// dx.doi.org/10.1111/j.1365-2621.1978.tb00809.x

BRUNAUER, S. et al. On the theory of Van de Walls adsorption of gases. Journal of the American Chemical Society, v. 62, n. 7, p. 1723-1732, 1940. http://dx.doi.org/10.1021/ja01864a025

BULL, H. B. Adsorption of water vapor by proteins. Journal of the American Chemical Society, v. 66, n. 9, p. 1499-1507, 1944. http:// dx.doi.org/10.1021/ja01237a025

CHANTARO, P.; DEVAHASTIN, S.; CHIEWCHAN, N. Production of antioxidant high dietary fiber powder from carrot peels. Food Science and Technology, v. 41, n. 10, p. 1987-1994, 2008.

CHIRIFE, J.; FERRO FONTAN, C.; BENMERGUI, E. A. The prediction of water activity in aqueous solutions in connection with intermediate moisture foods. IV. Aw prediction in aqueous non electrolyte solutions. Journal of Food Technology, v. 15, n. 1, p. 59-70, 1980. http://dx.doi.org/10.1111/j.1365-2621.1980. tb00919.x

DOYMAZ, I. The kinetics of forced convective air-drying of pumpkin slices. Journal of Food Engineering, v. 79, n. 1, p. 243-248, 2007. http://dx.doi.org/10.1016/j.jfoodeng.2006.01.049

GABAS, A. L.; MENEGALLI, F. C.; TELIS-ROMERO, J. Water sorption enthalpy-entropy compensation based on isotherms of plum skin and pulp. Journal of Food Science, v. 65, n. 4, p. 680-684, 2000. http://dx.doi.org/10.1111/j.1365-2621.2000.tb16072.x
INTERNATIONAL UNION OF PURE AND APPLIES CHEMISTRY - IUPAC. Reporting physisorption data for gas/solid systems. Pure and Applied Chemistry, v. 57, n. 4, p. 603-619, 1985.

KAYMAK-ERTEKIN, F.; GEDIK, A. Sorption isotherms and isosteric heat of sorption for grapes, apricots, apples and potatoes. Lebensmittel - Wissenschaft und Technologie, v. 37, n. 4, p. 429-438, 2004.

KRINSKY, N. I. Actions of Carotenoids in Biological Systems. Annual Review of Nutrition, v. 13, p. 561-587, 1993. http://dx.doi. org/10.1146/annurev.nu.13.070193.003021

LEWICKI, P. P. The applicability of the GAB model to food water sorption isotherms. International Journal of Food Science and Technology, v. 32 , n. 6, p. 553-557, 1997. http://dx.doi. org/10.1111/j.1365-2621.1997.tb02131.x

LOMAURO, C. J.; BAKSHI, A. S.; LABUZA, T. P. Evaluation of food moisture sorption isotherm equations part I: Fruit, vegetable and meat products. Food Science and Technology, v. 18, n. 2, p. 111-117, 1985.

MATHLOUTHI, M.; ROGÉ, B. Water vapour sorption isotherms ad the caking of food powders. Food Chemistry, v. 82, n. 1, p. 61-71, 2003. http://dx.doi.org/10.1016/S0308-8146(02)00534-4

MAYOR, L. et al. Water sorption isotherms of fresh and partially osmotic dehydrated pumpkin parenchyma and seeds at several temperatures. European Food Research Technology, v. 220, n. 2, p. 163-167, 2005. http://dx.doi.org/10.1007/s00217-004-1065-4

MAZZA, G.; LEMAGUER, M. Dehydration of onion: Some theoretical and practical considerations. Journal of Food Technology, v. 15, n. 2, p. 181-194, 1980. http://dx.doi.org/10.1111/j.1365-2621.1980. tb00930.x

MICROCAL SOFTWARE, INC. One Roundhouse Plaza. Northampton: Microcal Software, Inc., 1997

MORAES, M. A.; ROSA, G. S.; PINTO, L. A. A. Moisture sorption isotherms and thermodynamic properties of apple Fuji and garlic. International Journal of Food Science and Technology, v. 43 , n. 10, p. 1824-1831, 2008. http://dx.doi.org/10.1111/j.13652621.2008.01716.x

MOREIRA, R.; CHENLO, F.; TORRES, M. D. Simplified algorithm for the prediction of water sorption isotherms of fruits, vegetables and legumes based upon chemical composition. Journal of Food Engineering, v. 94, n. 3-4, p. 334-343, 2009. http://dx.doi. org/10.1016/j.jfoodeng.2009.03.026

MUJUMDAR, A. S. Drying Fundamentals. In BAKER, C. G. J. (Ed.). Industrial Drying of Foods. Baker: Blackie Academic \& Professional, 1997. p. 7-30.

PAPADAKIS, S. E. et al. Correlations for the equilibrium moisture content of solids. Drying Technology, v. 11, n. 3, p. 543-553, 1993. http://dx.doi.org/10.1080/07373939308916843

PARK, K. J.; YADO, M. K. M.; BROD, F. P. R. Obtenção das isotermas de sorção e modelagem matemática para a pêra bartlett (Pyrus sp.) com e sem desidratação osmótica, Ciência e Tecnologia de Alimentos, v. 21, n. 1, p. 73-77, 2001.

RESENDE, O. et al. Isotermas e Calor Isostérico de Sorção do Feijão. Ciência e Tecnologia de Alimentos, v. 26, n. 3, p. 626-631, 2006.

RIZVI, S. S. H. Thermodynamic properties of foods in dehydration. In: RAO, M. A.; RIZVI, S. S. H. (Eds.). 2th ed. Engineering properties of foods. New York: Marcel Dekker, 1995. p. 223-309.

RIZVI, S. S. H.; BENADO, A. L. Thermodynamic properties of dehydrated foods. Food Technology, v. 38, n. 3, p. 83-92, 1984.

RODRIGUEZ-AMAYA, D. B.; KIMURA, M.; AMAYA-FARFAN, J. Fontes Brasileiras de Carotenóides: Tabela Brasileira de 
Composição de Carotenóides em Alimentos. Brasília: Ministério do Meio Ambiente, Secretaria de Biodiversidade e Florestas, 2008. $100 \mathrm{p}$.

TSAMI, E. et al. Heat of sorption of water in dried fruits. International Journal of Food Science and Technology, v. 25, n. 3, p. 350-359, 1990. http://dx.doi.org/10.1111/j.1365-2621.1990.tb01092.x

UNIVERSIDADE DE CAMPINAS - UNICAMP. Tabela brasileira de composição de alimentos - TACO. Versão 2. 2. ed. Campinas: UNICAMP/NEPA, 2006.

VAN DEN BERG, C.; BRUIN, S. Water activity and its estimation in food systems: theoretical aspects. In: ROCKLAND, L. B.; STEWART,
G. F. (Eds.). Water activity: influences on food quality. New York: Academic Press, 1981.

VEGA-GÁLVEZ, A. et al. Moisture sorption isotherms and isosteric heat of red bell pepper (var. Lamuyo). Journal of Food Science, v. 13, n. 4, p. 309-316, 2007.

VEGA-GÁLVEZ, A. et al. Mathematical modelling of moisture sorption isotherms and determination of isosteric heat of blueberry variety O'Neil. International Journal of Food Science and Technology, v. 44, n. 10, p. 2033-2041, 2009.

WOLFE, K. L.; LUI, R. H. Apple peels as a value-added food ingredient. Journal of Agricultural and Food Chemistry, v. 51, n. 6, p. 1676-1683, 2003. http://dx.doi.org/10.1021/jf025916z 